\title{
広範囲熱傷における全身管理
}

熊本赤十字病院整形外科
中 島 英 親・平 良
中 根 惟 武・陣 内 卓 雄
米 満 弘 之

\section{The Treatment of severely burned Patients}

\author{
By
}

\author{
H. Nakashima, M. Taira, T. Nakane, T. Jinnai \\ and $\mathrm{H}$. Yonemitsu \\ Orthopedic Surgery, Red Cross Hospital, Kumamoto
}

We had six patients who are received, 1 st, 2 nd and 3rd degree burns over $60 \%$ of the bodydsurface. Emergency and early treatments of burn shock by intravenous and oral administration were done at Red Cross Hospital, Kumamoto.

Only one of them left our hospital on foot after 5 months of hospitalization and five patients died. We studied the fluid therapy of them.

$$
\text { はじめに }
$$

熊本赤十字病院が，昨年 4 月に救急病院として開設 され，熱傷は，整形外科を中心に取り扱っている．最 近，広範囲熱傷が多くなり，熱傷の局所治療のみでは 解決されず，全身管理が，重要な問題となっている. われわれは，1年間で， $60 \%$ 以上の熱傷 6 例を 経験 したので，補液を中心に全身管理について，多少の考 察を加え報告する。

$$
\text { 方 法・症 例 }
$$

患者が，運ばれた時点で，初期の全身管理として， CVP 測定をか子小て，2 力所の血管を確保し，次に留 置カテーテルを施行し, vital sign, CVP をチエッ クし，時間尿を測定した。そして，hypovolemic shock に対処するため熱傷面積は，成人には Walla$\mathrm{ce}^{2)}$ らの「の法則」， 幼児には Blocker の「5の 法則」を用い，算出し補液計画をたてた。原則として Evance の公式を用いた。 但し, Evance の公式で は，熱傷面積 $50 \%$ 以上は $50 \%$ として計算し，全量が $10000 \mathrm{ml}$ 以上となるときは，10000 ml を上限とする ことになっているので, 今回のように，60\%以上の
熱傷を対象にする場合, 2 日目以後は, 時間尿, CVP 血清蛋白, $\mathrm{Hb}, \mathrm{Ht}$ 等の值を考慮し, Evance 法にと らわれず，補液の計画をたてた．また患者が経口摂取 可能なかぎり水分をとらせた，尿量は成人で，50〜 $100 \mathrm{ml} /$ hour を目標にし, 尿量が少ないときは, CVP を参考にし, infusion test や manitol test 等を積 極的に行ない, Lasix を頻回に用い尿量の維持につと めた，局所療法としては，創部を十分に洗浄，消毒 し，清潔シーツで被うようにした。症例は熱傷面積 $60 \%$ 以上の症例 6 名である.内訳は，60\% 2 名， 85 $\% 1$ 名, $80 \% 1$ 名, $75 \%$ 名, $70 \% 1$ 名で, 男子 4 名，女子 2 名である. 気道熱傷を伴なったものは， 3 名でした（表1）.

\section{症例を供覧する}

症例 I. 75 才男于. 着衣引火による $85 \%$ 広範囲熱 傷, 既往として脳卒中, 肝障害あり, 熱傷後 6 日目で 死亡したが，その間ほとんど尿量が得られなかった。 CVP はかなり変動している．水分の経口掑取がまっ たく出来ず, また全体的に補液が少ないのが目立つ. 諸検査では血清蛋白, $\mathrm{Hb}$ 等の一次的低下がみられる がほぼ正常範囲にある，尿素窒素は日ごとの著明な上 
表 1 熱傷症例

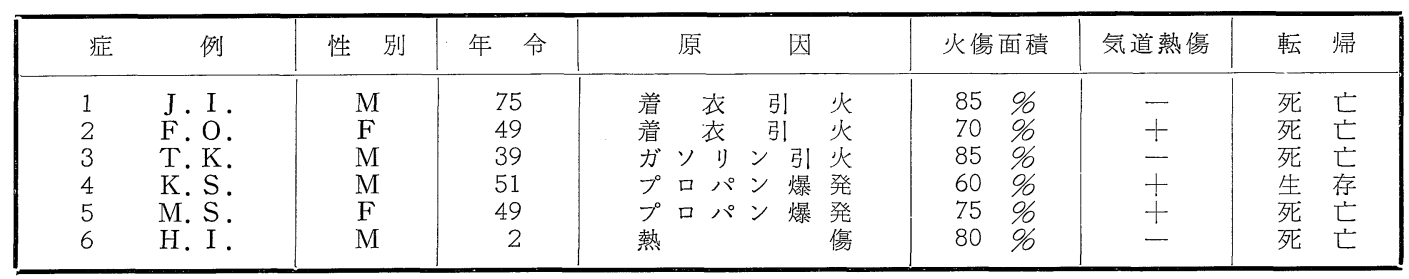

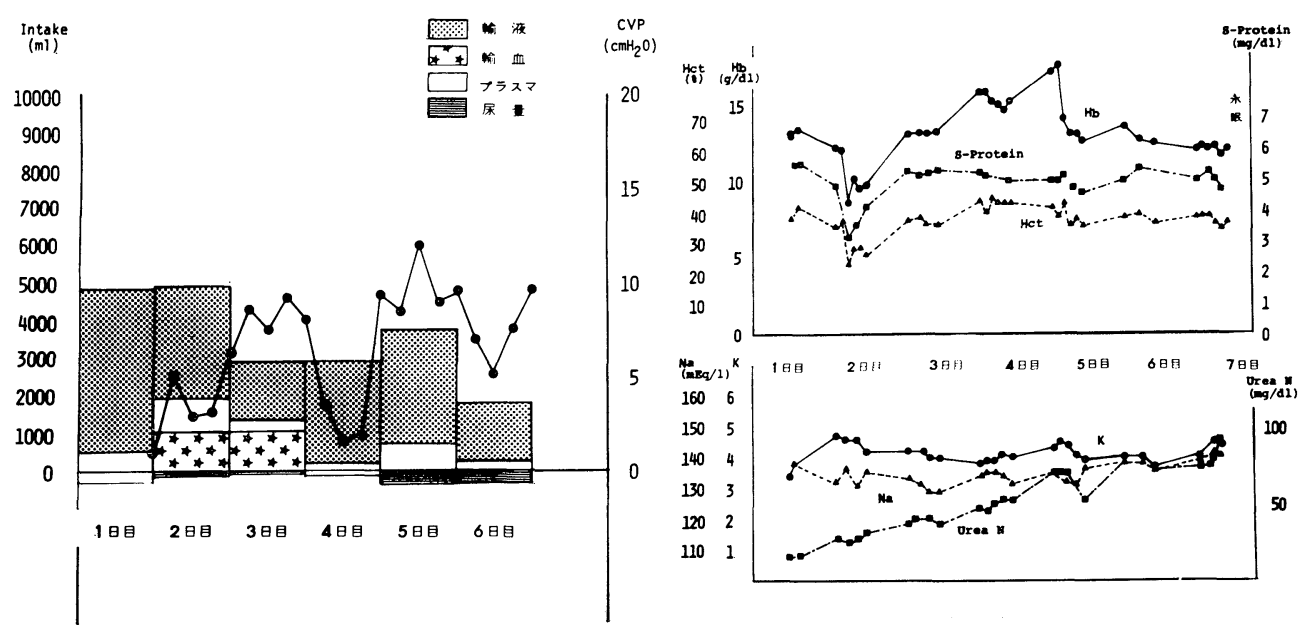

図 1 J.I. 75 才

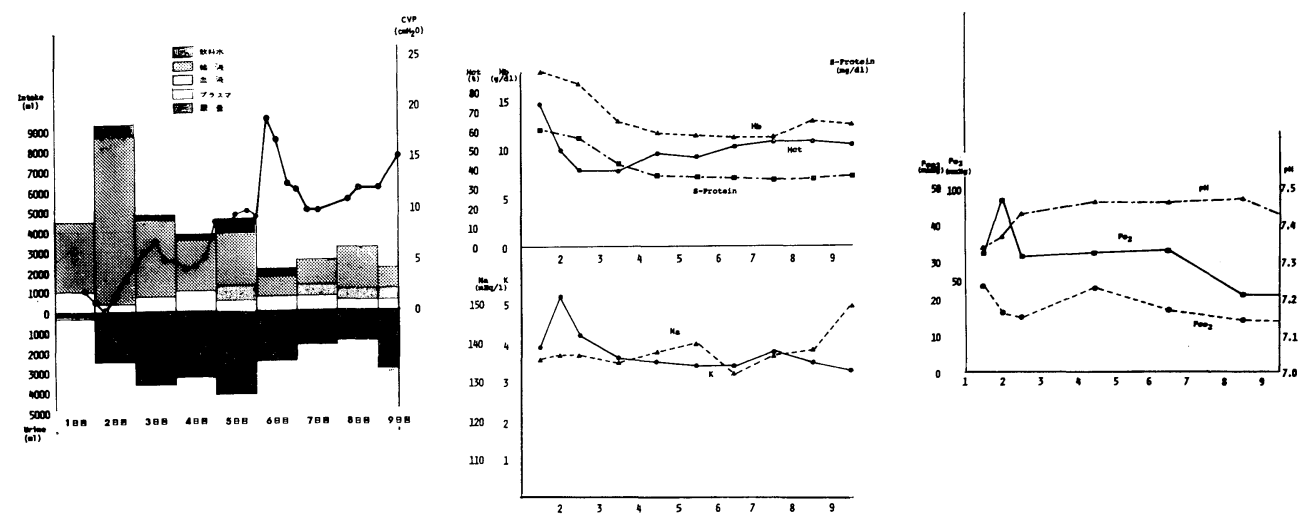

図2 J.K. 39才领

昇をみとめた（図1）。

症例 II . 39 才男子．ガソリンによる着衣引火で 85 $\%$ の広範囲熱傷である，尿量も渐時増加し，全身状態 も良好でしたが， 6 日目より，CVP 值の急激な上昇 がみられ，胸部に湿性亏音を聴取し，胸部レ線にて肺 水腫様陰影をみとめたため, 補液量を減少させた。同
時に尿量も減少し，経口摂取も不可能となり，肺合作 症が改善せぬまま死亡した。血液ガスでは， $\mathrm{PO}_{2}$ の 7 日目以後の低下が著明である。諸検査では, 血清蛋白 の低下がみられるが，著明なものではない（図2）， 症例 III. 51 才男子. プロパンガス爆発による $60 \%$ 広範囲熱傷で, 気道熱傷を伴った例で, 3 日目以後, 

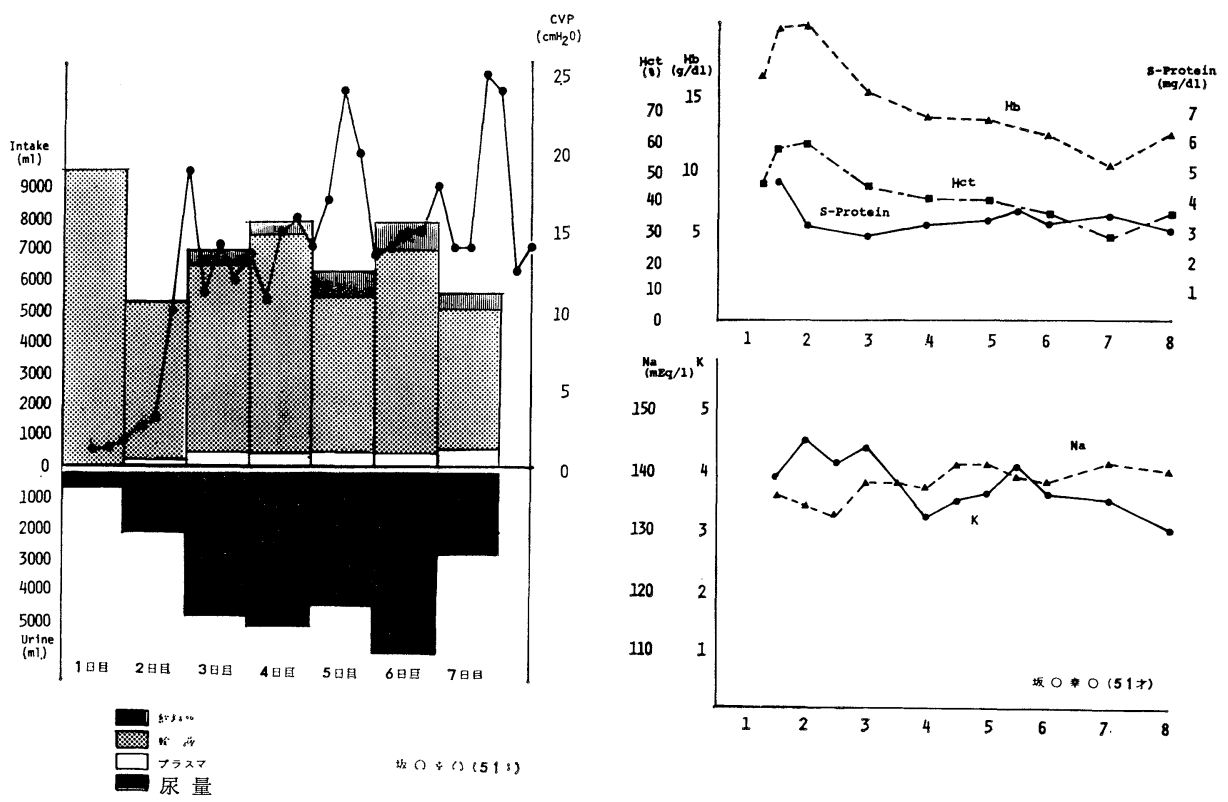

図 3

K. S. 51才 令

尿量の増加がみられ， CVP が次第に正常にもどって いる，諸検査では，血清蛋白が著明に低いのが特徴で ある。これが唯一の生存例である(図3).

以上の症例の十分な検討の結果として，

1. 血清蛋白および Ht 值は，全般的に $1 〜 2$ 日目 まで逆相関しているが，3日目以後は比例して減少し ている.

2. 電解質の中で，カリウム，ナトリウムは相関し て,ほほ正常範囲にある。

3. CVP は 2 日目まで $0 \sim 5 \mathrm{~cm} \mathrm{H}_{2} \mathrm{O}$ であるが， 補液の充足とともに，ほほ $15 \mathrm{~cm} \mathrm{H}_{2} \mathrm{O}$ になる。

4. $\mathrm{PO}_{2}$ は 4 日目以後次第に下降する.

5 . 尿量は 2〜 3 日目より利尿期に移行した場合 は，予後が良いようである。

\section{問題点, 考察}

上記の結果から, 尿量の改善が特に重要である.そ の改善の指標として，2〜3日目より利尿期に移行し た症例は予後が良かったので，早期の利尿期を考光 た。利尿期については，川崎4) らの研究で，5 日以内 に多尿期をむかえる群と，5 日以後の尿量の増加する 群の 2 つに分けた場合, 後者の方が一般的で, 前者は 過剩補液の症例にみられ，臨床的肺水腫を呈するとと
が多いとしているが，多少相違するようである。次 に，如何にして補液で third space を補うか，また その補液内容についても lactated ringer's solutions $^{337)}$ 高張 $\mathrm{Na}$ 溶液等と問題が多い上うである.わ れわれは lactated ringer's solutiom を主体にして 補液をした。今後高張 $\mathrm{Na}$ 溶液等を用いて比較検討 するつもりである．体液のバランスについては，Hb, Ht 血清蛋白を如何飞考慮して補液しても，細胞外淮 の一部の変化をとらえただけで，多くをしめる細胞内 液の変化の測定が困難な現況では，補液の指標として 十分でないてとがわかった。感染，低栄養対策は，非 常に困難で，特に尿量が十分量になり， shock 期か ら離脱する．5〜 7日目あたりから，感染，低栄養が 著明におこり，死因と関係の深い肺合併症と重要な関 係があると思われる．肺合併症が多いのと関連し，6 名中 3 名が，気道熱傷を伴っている。乙れは，Stone のいう，(1)顔面の熱傷，(2)鼻，口周辺の熱傷，鼻毛の こげ，(3)閉鎖室内の受傷のうち2つ以上があれば，気 道熱傷として处置する必要があるとのととを参考した 場合であるが，非常に適確な基準で，とれらの3 例 は，一様に肺合併症をおしした。治療に 個体差があ り，短時間のうちに症状の急変をおてす広範囲熱傷に おいて，詳細な集中管理，適確な判断という点から， 
熱傷班をつくり，集中管理5!6) のもとにおける治療の 必要性を痛感した。

\section{文献}

1) Moore, F. D.: Metabolic care of surgical patient, Surg, 56: 505, 1964.

2) Wallace, A. B.: The exposure treatment of burns, Lancet, 260: 501, 1951.

3）穴沢雄作：熱傷の治療. 治療, 56:137-144, 1974.

4）三崎勝弘：広範囲熱傷にみられた急性肺水腫の
検討. 外科治療, $27: 693,1972$.

5）関口忠男：熱傷の治療. 臨床と研究. 1:48, 1971.

6) 森田 亨: Advanced Life Support. 外科治 療, 33: 583-589, 1975.

7）八木義弘：熱傷. 治療, 56：590-594, 1974.

\section{発 言新日鉄八幡病院整形 内村 正英}

われわれの病院においては, 広範囲重傷熱傷の初期 に対し, 臓器の DIC を想定し, ヘパリンの投与を行 なっている.

\title{
アキレス腱皮下断裂の保存的治療
}

\section{九州厚生年金病院}

渡辺甲作・福且俊宗

\section{Non-Surgical Treatment of Tendo Acillis Rupture}

By

\author{
K. Watanabe and T. Fukuda \\ Orthopedic Department, Kyushu Welfare Pension Hospital, \\ Kitakyushu-City, Japan
}

Twelve rupture of the achilles sendon were treated non-surgical.

The method of the treatment was immobilization in a walking plaster boot cast applied with foot in gravity equinus position for eight weeks. After the cast removed, the patient used a $2.5 \mathrm{~cm}$. heel lift for four week and undertook active gastrocnemius strengthening exercise. The results of the treatment showed ten satisfactory, and one fair for old rupture.

A rerupture occured two days after initial plaster immobilization and was subsequently operated.

アキレス腱断裂の治療は 1880 年, Maydle が初め てアキレス腱を縫合して以来, 手術的治療が最良の方 法とされてきた。しかし 1968 年, Robert Lea 等は アキレス腱の保存的治療を提唱し, 良好な成績であっ たと発表した。私たちも，昭和 48 年 4 月から, 昭和 51 年 3 月までに 12 例のアキレス腱皮下断裂のギプス 治療をやってみたのでその結果について報告した。症 例は 12 例で, 完全断裂 11 例, 不全断裂 1 例で, 性別 は男性 2 例, 女性 10 例, 患側は左 9 例, 右 3 例, 年 令は 16 才から 68 才で平均 38.8 才, 受傷から初診ま での期間は当日から，21 日で平均 4 日，追跡調査期 間は 6 力月から 36 力月で, 平均 18.1 力月であった.
治療法は足下垂位で膝下部より足尖まで歩行ギプスを 8 週間行い、先ず前半の 4 週間は松葉杖で軽く荷重を かけ，後半の 4 週間はギプスまきかえの後，松葉玟に て積極的に荷重をかける. 8 週後, ギプスを除去し $2.5 \mathrm{~cm}$ から $3 \mathrm{~cm}$ かかとを高くした鞉またはつっか けなどの履物を常時使用し, 下腿三頭筋の訓練を始め る. 12 週間後, 普通の歩行を開始し, つま先立ちの 練習を行う．結果は 12 例中 1 例， 8 週後ギブスを除 去して，ヒールにむえた後 2 日目につまずいて再断裂 をおこした1例を除いて良好な成績であった，最終調 查時点で成績を判定してみると，機能的にほとんど正 常で, 患足つま先立ちが可能なもの優, 輅い痛みを時 